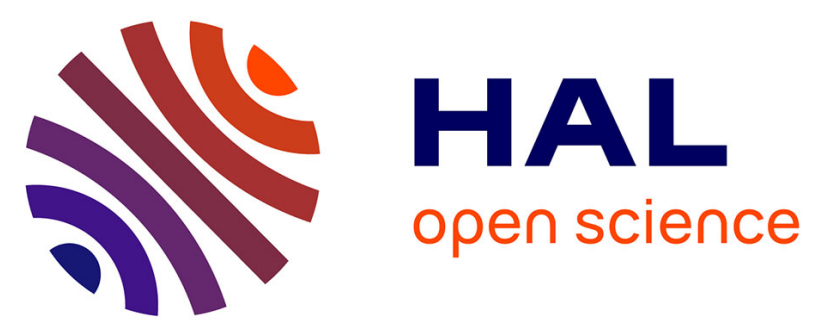

\title{
Predicting quality, texture and chemical content of yam ( Dioscorea alata L.) tubers using near infrared spectroscopy
}

Adou Emmanuel Ehounou, Denis Cornet, Lucienne Desfontaines, Carine Marie-Magdeleine, Erick Maledon, Elie Nudol, Gregory Beurier, Lauriane Rouan, Pierre Brat, Mathieu Lechaudel, et al.

\section{To cite this version:}

Adou Emmanuel Ehounou, Denis Cornet, Lucienne Desfontaines, Carine Marie-Magdeleine, Erick Maledon, et al.. Predicting quality, texture and chemical content of yam ( Dioscorea alata L.) tubers using near infrared spectroscopy. Journal of Near Infrared Spectroscopy, 2021, 29 (3), pp.128-139. 10.1177/09670335211007575 . hal-03213799

\section{HAL Id: hal-03213799 \\ https://hal.inrae.fr/hal-03213799}

Submitted on 30 Apr 2021

HAL is a multi-disciplinary open access archive for the deposit and dissemination of scientific research documents, whether they are published or not. The documents may come from teaching and research institutions in France or abroad, or from public or private research centers.
L'archive ouverte pluridisciplinaire HAL, est destinée au dépôt et à la diffusion de documents scientifiques de niveau recherche, publiés ou non, émanant des établissements d'enseignement et de recherche français ou étrangers, des laboratoires publics ou privés.

\section{(ㄷ)(1) $\$$}

Distributed under a Creative Commons Attribution - NonCommerciall 4.0 International 


\title{
Predicting quality, texture and chemical content of yam (Dioscorea alata L.) tubers using near infrared spectroscopy
}

\author{
Adou Emmanuel Ehounou ${ }^{1,2}$, Denis Cornet ${ }^{3,4}$ (D) , Lucienne Desfontaines ${ }^{5}$, \\ Carine Marie-Magdeleine ${ }^{6}$, Erick Maledon ${ }^{4,7}$, Elie Nudol ${ }^{4,7}$, \\ Gregory Beurier $^{3,4}$, Lauriane Rouan ${ }^{3,4}$, Pierre Brat ${ }^{4,8}$, \\ Mathieu Lechaudel ${ }^{4,8}$, Camille Nouss ${ }^{9}$, Assanvo Simon Pierre N'Guetta ${ }^{1,2}$, \\ Amani Michel Kouakou ${ }^{2}$ (D) and Gemma Arnau ${ }^{4,7}$
}

\begin{abstract}
Despite the importance of yam (Dioscorea spp.) tuber quality traits, and more precisely texture attributes, high-throughput screening methods for varietal selection are still lacking. This study sets out to define the profile of good quality pounded yam and provide screening tools based on predictive models using near infrared reflectance spectroscopy. Seventy-four out of 216 studied samples proved to be moldable, i.e. suitable for pounded yam. While samples with low dry matter $(<25 \%)$, high sugar $(>4 \%)$ and high protein $(>6 \%)$ contents, low hardness $(<5 \mathrm{~N})$, high springiness $(>0.5)$ and high cohesiveness $(>0.5)$ grouped mostly non-moldable genotypes, the opposite was not true. This outline definition of a desirable chemotype may allow breeders to choose screening thresholds to support their choice. Moreover, traditional near infrared reflectance spectroscopy quantitative prediction models provided good prediction for chemical aspects $\left(R^{2}>0.85\right.$ for dry matter, starch, protein and sugar content), but not for texture attributes $\left(R^{2}<0.58\right)$. Conversely, convolutional neural network classification models enabled good qualitative prediction for all texture parameters but hardness (i.e. an accuracy of $80,95,100$ and $55 \%$, respectively, for moldability, cohesiveness, springiness and hardness). This study demonstrated the usefulness of near infrared reflectance spectroscopy as a high-throughput way of phenotyping pounded yam quality. Altogether, these results allow for an efficient screening toolbox for quality traits in yams.
\end{abstract}

\section{Keywords \\ Yam (Dioscorea alata L.), quality, texture, near infrared spectrometry, convolutional neural network}

Received 27 January 2021; accepted 7 March 2021

\section{Introduction}

Yams (Dioscorea spp.), which are important crops for food security, are grown in tropical and sub-tropical regions. ${ }^{1}$ They are dioecious herbaceous vines belonging to a $\mathrm{C} 3$ monocotyledonous genus cultivated for their starchy tubers. ${ }^{2} D$. rotundata and D. alata are the most important cultivated species and both belong to the same botanical section, i.e. Enantiophyllum. Greater yam (D. alata) ranks second in production importance, but it is the most widely cropped species in the world. ${ }^{3}$ This species offers unique advantages in terms of potential yield, especially under low-fertility soil conditions (e.g. ease of propagation, early vigor for weed suppression and storability of tubers). ${ }^{4,5}$ Yams are consumed in several forms (e.g. boiled, pounded, fried, baked, and roasted). In West Africa, where over $95 \%$ of the

\footnotetext{
${ }^{1}$ Université Félix Houphouët Boigny, UFR Biosciences, Abidjan, Côte d'Ivoire

${ }^{2}$ CNRA, Station de Recherche sur les Cultures Vivrières, Bouaké, Côte d'Ivoire

${ }^{3}$ CIRAD, UMR AGAP Institut, F-34398 Montpellier, France

${ }^{4} U M R$ AGAP Institut, Univ Montpellier, CIRAD, INRAE, Institut Agro, F34398 Montpellier, France

${ }^{5}$ INRAE, UR 1321 ASTRO Agrosystèmes tropicaux. Centre de recherche Antilles-Guyane, Petit-Bourg, France

${ }^{6}$ INRAE, UR 0143 URZ Unité de Recherches Zootechniques. Centre de recherche Antilles-Guyane, Petit-Bourg, France

${ }^{7}$ CIRAD, UMR AGAP Institut, Petit-Bourg, Guadeloupe, France

${ }^{8}$ CIRAD, UMR Qualisud, Capesterre-Belle-Eau, Guadeloupe, France

${ }^{9}$ Cogitamus Laboratory, Laboratoire Cogitamus, Montpellier, France

Corresponding author:

Denis Cornet, CIRAD Centre de Montpellier, UMR Agap Institut, F-34398

Montpellier, France.

Email: denis.cornet@cirad.fr
} 
world's yams are produced, ${ }^{6}$ pounded yam is the preferred consumption form. It is prepared by pounding the cooked tuber and kneading it into a sticky paste. ${ }^{7}$ In this respect, $D$. rotundata is usually preferred to D. alata owing to its ease of dough formation when pounded. ${ }^{7}$ However, several studies have shown that some genotypes of $D$. alata have the ability to form good dough, comparable to that of D. rotundata. ${ }^{8,9}$

The importance of yams in terms of food security has led to the establishment of several genetic improvement programs for $D$. alata throughout the tropical regions, in order to develop new varieties with high yield, good food quality and resistance to pests and diseases. ${ }^{3,10-13}$ Sensory quality evaluations of new genotypes are mostly carried out using sensory panels. It is a laborious and lengthy process that lacks a high-throughput phenotyping method. For this reason, the organoleptic qualities of new varieties are assessed at the end of the breeding process. By that time, only a few genotypes remain and the chance of identifying high quality varieties is low. As a result, improved varieties are rarely adopted by end-users.

Organoleptic properties depend on several physico-chemical and textural characteristics. Dry matter, starch, proteins and sugar contents are important quality traits. Martin (1974) observed in Puerto Rico (USA) that high dry weights are associated with fine structure, dense feel and high quality. ${ }^{14}$ Lebot et al (2005) observed that varieties with good boiled quality are characterized by high dry matter, starch and amylose contents. ${ }^{15}$ Physico-chemical analysis studies showed that varieties with good poundability are also characterized by high dry matter contents. ${ }^{16,17}$ Lastly, Brunnschweiler (2004) showed that pounded D. rotundata exhibited greater firmness, elastic recovery, gumminess and cohesiveness than D. alata varieties. ${ }^{18}$ Several sensorial tests using trained or hedonic testing have been carried out in different West African countries in order to identify which texture and taste attributes of pounded yam are the most important. Five parameters are often mentioned in relation to quality, namely firmness, ease of molding, smooth appearance (absence of lumps), springiness and sweetness. ${ }^{8,16,19-21}$

The textural properties of pounded yam can be measured using a double compression test with a Textural Profile Analyser. ${ }^{22}$ This method can be used to quantify different parameters (e.g. hardness, cohesiveness and springiness) linked to texture attributes. It has been successfully used to determine the textural quality of various food products, such as soybean-derived gels, banana, cassava roots or yam tubers. ${ }^{23-27}$ However, chemical and textural characterization (both sensorial and TPA analysis) are costly, laborious and time-consuming. A highthroughput phenotyping method is required to be able to screen large numbers of breeding lines. In this regard, near infrared reflectance (NIR) spectroscopy has become a widely used method of quality control in the food processing industry. ${ }^{28,29}$ It is a rapid, cost-effective and non-destructive technique allowing the simultaneous determination of major chemical constituents. NIR spectroscopy has been used to predict the content of major constituents in sweet potato, cassava, yam and taro crops. ${ }^{12,30}$

This study investigated the potential of NIR spectroscopy as a tool for chemical and textural characterization of $D$. alata tubers. The objectives of the present study were to (1) analyze the chemical and textural characteristics of a panel representative of the genetic diversity of D. alata, and (2) assess the potential of NIR spectroscopy as a tool for screening quality attributes.

\section{Materials and methods}

\section{Plant material and sample preparation}

Twenty-seven D. alata accessions (Table 1) and breeding lines from various geographical origins were analyzed. In order to broaden the genetic diversity studied, the accessions were selected from previously obtained genotypic and quality data. ${ }^{31}$ Of the selected genotypes, Florido and Bete Bete are the two most cultivated varieties of $D$. alata in Ivory Coast. Bete Bete is considered as a good quality genotype for preparing pounded yam, ${ }^{32}$ and was considered as a reference variety throughout this study.

Accessions were planted together in the same plot at the Roujol experimental station $\left(16^{\circ} 10^{\prime} 56^{\prime \prime} \mathrm{N}\right.$, $61^{\circ} 35^{\prime} 24^{\prime \prime} \mathrm{W}, 10$ a.s.1., Petit-Bourg, Guadeloupe, France) during two cropping seasons (i.e. 2016 and 2017). At harvest, three to five tubers of each variety were peeled with a knife and washed. The head and the tail were removed, and then the tuber was cut longitudinally into two equal parts. The first half was sliced into chips that were oven-dried at $60^{\circ} \mathrm{C}$ for $72 \mathrm{~h}$ and milled into flour using a stainless steel grinder (M-Mandine $150 \mathrm{~W}$, Carrefour, Levallois, France). The granule size was homogenized using a $200 \mu \mathrm{m}$ sieve. After setting aside $5 \mathrm{~g}$ for NIR spectroscopic analysis, samples of $50 \mathrm{~g}$ were sent for chemical analysis (i.e. starch, sugar and protein contents at the Laboratoire d'Analyses Agricoles Teyssier, Bordeaux, France). In all, 174 yam flour samples (93 flour samples in 2016 and 81 flour samples in 2017) were prepared for further analysis.

The other half tuber was cut into pieces of about $5 \mathrm{~mm}$ thick and placed with 1.51 of water in a pressure cooker. Three identical pressure cookers were used to prepare three samples of each variety at a time. After cooking, the pieces were pounded with a mechanical pounder (Bluesky model, NIF A-2842270, China). The mechanical pounder was used in order to ensure uniform conditions for sample preparation, which could not have been guaranteed with the 
Table 1. Details of accessions with their accession code, geographical origin, local name, ploidy level and accession type included in the study.

\begin{tabular}{|c|c|c|c|c|c|c|}
\hline Code accession & Geographical origin & Local name & $\begin{array}{l}\text { Type of } \\
\text { accessiona }\end{array}$ & Ploidy level & Flowering & $\begin{array}{l}\text { Genetic diversity } \\
\text { groupb }\end{array}$ \\
\hline CT133 & Vanuatu & Ptris & C & 2 & Male & 3 \\
\hline CT177 & Vanuatu & Peter & C & 2 & Male & 6 \\
\hline CT256 & Benin & Florido & C & 2 & Male & 7 \\
\hline Plim-G & France (Guadeloupe) & Plimbite & C & 2 & Male & _ \\
\hline Kin-G & France (Guadeloupe) & Kinabayo & C & 2 & Female & 2 \\
\hline Pac-P & France (Guadeloupe) & Bete Bete & C & 2 & Female & 8 \\
\hline Kab-L & France (Guadeloupe) & Kabusa & C & 2 & Male & 3 \\
\hline PT-IG-00074 & Barbados & Oriental & C & 2 & Female & 2 \\
\hline STVB & France (Guadeloupe) & St Vincent blanc & c & 2 & Female & 4 \\
\hline STVV & France (Guadeloupe) & St Vincent violet & C & 2 & Female & 4 \\
\hline Div-PB & France (Guadeloupe) & Divin & C & 2 & Female & _ \\
\hline PT-IG-00033 & USA (Puerto Rico) & Pyramide & C & 2 & Male & 1 \\
\hline CT143 & Vanuatu & Malalagi & C & 2 & Male & 3 \\
\hline CT202 & Vanuatu & Nureangdan & C & 3 & Male & 14 \\
\hline CT198 & Vanuatu & Noulelcae & C & 4 & Female & 16 \\
\hline CT138 & Vanuatu & Tagabé & C & 4 & Female & 18 \\
\hline CT148 & Vanuatu & Toufi Tetea & C & 4 & Male & 18 \\
\hline $160 \mathrm{DD}$ & France (Guadeloupe) & Sinoua & c & 4 & _- & _- \\
\hline $74 \mathrm{~F}$ & India & Hyb $2 x-74 F$ & BRL & 2 & Female & _- \\
\hline $14 \mathrm{M}$ & India & Hyb $2 x-14 M$ & $B R L$ & 2 & Male & _- \\
\hline $\mathrm{H} 4 \mathrm{X} 431$ & France (Guadeloupe) & Dou & $B R L$ & 4 & Female & _- \\
\hline H4X105 & France (Guadeloupe) & Tiviolet & $B R L$ & 4 & Female & _ \\
\hline H4X172 & France (Guadeloupe) & Hyb $4 x-172$ & $B R L$ & 4 & Female & _- \\
\hline $\mathrm{H} 4 \mathrm{X} 242$ & France (Guadeloupe) & Roujol & $\mathrm{BRL}$ & 4 & Male & - \\
\hline $\mathrm{H} 4 \mathrm{X} 131$ & France (Guadeloupe) & Hyb $4 x-131$ & $B R L$ & 4 & Male & - \\
\hline $\mathrm{H} 4 \mathrm{X} 200$ & France (Guadeloupe) & Hyb $4 x-200$ & $B R L$ & 4 & Female & _- \\
\hline H4X274 & France (Guadeloupe) & Hyb $4 x-274$ & BRL & 4 & Male & $\ldots$ \\
\hline
\end{tabular}

${ }^{\mathrm{a} C}$, Landraces; BRL, Breeding lines.

${ }^{\mathrm{b}}$ Genetic groups identified in Arnau et al. (2017).

traditional practice of manual kneading in a mortar with a pestle. 20,33

\section{Texture evaluation}

After pounding, each paste obtained was assessed for its moldability. The moldability of the dough is its ability to form a ball with the hand. Moldability was assigned a binary score depending on whether or not the dough was easily malleable (2: good dough, 1: bad dough).

The textural properties of pounded samples were characterized using texture profile analysis (TPA) with two compression cycles. Samples of yam pastes were formed using a mold (diameter, $25 \mathrm{~mm}$; height, $18 \mathrm{~mm}$ ) and wrapped in plastic immediately after pounding to prevent surface drying. Nine different pounded yam samples were analyzed for each variety (i.e. three replicates per tuber and three tubers per genotype). TPA was carried out by compressing the yam samples using a TA.Xt2i texture analyser (Stable Micro Systems, Godalming, U.K.). Data were acquired and integrated with Texture Exponent software from the same manufacturer. Each sample was placed horizontally and centered under the probe before measurement. The two compression cycles were achieved using a flat ended aluminum cylinder plunger (i.e. probe $\mathrm{P} / 75$; diameter, $50 \mathrm{~mm}$ ) to $50 \%$ of its initial height. The trigger force was $0.049 \mathrm{~N}$ and the test speed was set at $1.0 \mathrm{~mm} \mathrm{~s}^{-1}$. All analyses were carried out at a room temperature of $26^{\circ} \mathrm{C}$.

The force deformation curve was evaluated according to Bourne (2002) and Rosenthal (1999). ${ }^{34,35}$ Hardness is defined as the maximum force on the first compression cycle. Cohesiveness is defined as a ratio between the positive area under the force-deformation curve of the second and the first compression cycles. Springiness is defined as the ratio between distances from the onset to peak force of the second to the first compression cycle.

\section{Chemical analysis}

Dry matter (DM), starch, sugar and protein contents were analyzed according to AFNOR and European Union methods. All measurements were expressed as a percentage of DM (as per standard NF V18-109). Starch was quantified using Ewers protocol (ISO 10,520). Sugars were quantified by the colorimetric method of Luff-Schoorl (CEE 98/54/CE). Total 
$\mathrm{N}$ content (considered as equivalent total proteins) was calculated using the Kjeldahl method (standard NF V18-100). All analyses were carried out in duplicate with accepted mean coefficients of variation $(3 \%$ for starch and sugars and $2 \%$ for proteins).

\section{Data analysis}

The chemical data (starch, proteins and sugars) and TPA texturometer data (hardness, cohesiveness and springiness) were analyzed using XLSTAT version 19.03.44616. A one-way ANOVA was used to analyze the differences in evaluated characteristics between genotypes. A Pearson correlation coefficient analysis was used to determine the correlation coefficients between different chemical and texture characteristics.

The relationship between chemical and TPA parameters was illustrated by a multivariate analysis (principal component analysis, PCA). The results of the PCA were represented by two plots, one for attributes and one for the varieties, with clusters based on hierarchical clustering on principal components (HCPC). The HCPC first built a hierarchical tree. The sums of within-cluster inertia values were calculated for each partition. The partition kept was the one with the highest relative loss of inertia.

\section{Spectra collection and sample selection}

NIR spectroscopy analyses were carried out in the food processing laboratory of INRAE's Tropical Animal Research Unit, UR143, in Guadeloupe (France). Two replicates of yam flour samples were scanned with a FOSS-NIRSystems model 6500 scanning monochromator (FOSS-NIRSystems, Silver Spring, MD, USA) equipped with an autocup. The spectroscopic procedures and data recording were conducted with ISIscan(TM) software (FOSS, Hillerød, Denmark). Each flour was placed in a small ring cup $36 \mathrm{~mm}$ in diameter, and reflectance spectra from 400 to $2500 \mathrm{~nm}$ were recorded at $2 \mathrm{~nm}$ intervals. Each spectrum represented the average of 32 scans. ${ }^{36}$ Each sample was scanned twice with two independent cups, in order to minimize the effect of particle size. The average spectrum of each sample was used for further chemometric analysis.

\section{Calibration and validation of regression models}

For all traits but hardness, modeling was done using WinISI software v4.10.0 (FOSS, NIR spectroscopy, Denmark) using a modified partial least squares regression (M-PLS). First, spectra and data outliers were eliminated following the Shenk and Westerhaus (1993) procedure. $^{36}$ Before developing a calibration model, two spectral outlier elimination cycles were set up on the 174 samples using the center algorithm, which calculated the Global $\mathrm{H}$ distance $(\mathrm{GH})$ with a cutoff of $\mathrm{GH}=3$. In this study, an outlier is defined as a sample that does not conform to the bulk of the population in terms of the spectral data. The samples were then divided into a calibration set (3/4) and a validation set (1/4). To select appropriate and representative samples of the calibration set, the SELECT algorithm was applied on the spectra. The number of samples in both calibration and validation set after outlier removal is given in Table 4. A 15-folds crossvalidation procedure was implemented to reduce overfitting $^{36}$ and split the calibration set into actual calibration and calibration test set allowing identifying the best pretreatments combination and model calibration equation. The validation set was finally used to evaluate the calibration equation. In order to solve problems associated with overlapping peaks and baseline correction, different mathematical pretreatments followed by some pretreatment algorithm were tested. Mathematical treatment parameters were the derivative order (D), the dimension of derivatives $(\mathrm{G})$, the degree of first smooth (S1) and the degree of second smooth (S2). Pretreatment algorithm then tested comprised standard normal variate and detrending (SNV), multi scatter correction (MSC), windowed multi scatter correction (WMSC) and Savitzky-Golay algorithm (SG). The choice of the best pretreatment parameters and combination was based on the standard error of calibration. Mathematical pretreatment $\left(\mathrm{MP}_{\mathrm{D}, \mathrm{G}}, \mathrm{S} 1, \mathrm{~s} 2\right)$ and pretreatment algorithm selected were $\mathrm{MP}_{2,8,8,1}$ followed by MSC for dry matter, starch and protein; $\mathrm{MP}_{2,8,8,2}$ followed by WMSC for sugar; and $\mathrm{MP}_{2,4,4,1}$ followed by SNV for springiness and cohesiveness.

Hardness was calibrated with the ChemFlow (https://chemproject.org/ChemFlow) open source software. Data pretreatment used a standard normal variate followed by the Savitzky-Golay algorithm with first order derivative, 13 window size and second degree polynomial. The multivariate distances were used as criteria for removing outliers (i.e. samples in the population that were more variable based on the spectra features). Then, principal component analysis (PCA) was performed followed by the calibration using nonlinear estimation by iterative partial least squares regression (NIPALS), ${ }^{37}$ with 4-fold cross validation and 20 latent variables.

At each step (i.e. cross-validation, calibration and validation), the standard error $\left(\mathrm{SE}_{\mathrm{CV}}, \mathrm{SE}_{\mathrm{C}}, \mathrm{SE}_{\mathrm{P}}\right.$ respectively) and the coefficient of determination $\left(\mathrm{R}_{\mathrm{CV}}^{2}, \mathrm{R}_{\mathrm{C}}^{2}\right.$ and $\mathrm{R}_{\mathrm{P}}^{2}$ respectively) were calculated. The best pretreatment and calibration model was selected using the highest $\mathrm{R}_{\mathrm{C}}{ }_{\mathrm{C}}$, and the lowest $\mathrm{SE}_{\mathrm{C}} \cdot{ }^{38}$ Moreover, the prediction ability of the different regression models was tested based on the ratio between standard deviation (SD) and the standard error ( $\mathrm{SE}_{\mathrm{P}}$ for validation step). All regression models were developed using the 1100-2498 nm interval range. 


\section{Calibration and validation of classification models}

In order to evaluate the feasibility of screening genotypes for quality when regression models were performing poorly, continuous texture attributes were binarized based on a variable's average (i.e. values strictly higher than the average were considered to have the traits, while others not). Classification models were then fitted in order to predict belonging to binary classes of hardness, cohesiveness, springiness and moldability.

The classification modeling strategy was based on convolutional neural network (CNN). Recently, machine learning techniques, such as convolutional neural networks (CNNs), have been suggested as a replacement for conventional regression techniques, such as principal component, PLS or support vector machine, due to their superior performance. ${ }^{39-42}$ The first advantage of $\mathrm{CNN}$ comes when classes are not linearly separable. In such cases the linear classifiers may be outperform by more sophisticated models able to deal with nonlinearity. Moreover, the innovation of convolutional neural networks rely on their ability to automatically learn together a large number of filters specific to a training dataset under the constraints of a specific predictive modeling problem, such as spectra classification. ${ }^{39}$ The result is highly specific features that can be detected anywhere on input spectra.

For the calibration of these models, all the spectra were kept without removing spectral outliers. Pretreatments, calibration and validation were carried out using python language (v3.6, https://www.pyth on.org) with a Keras framework (v2.1.5, https:// keras.io/) and a TensorFlow backend (v1.6.0, https://www.tensorflow.org). Samples were divided into a calibration set (60) and a validation set (21) using constrained random sampling keeping the same proportion of each class in the two sets.

First, a data (i.e. sample) augmentation was applied to the calibration set only. For each original sample, 30 synthetic spectra were generated using a combination of random translation and rotation of the original spectra. Then spectra presenting absorbance values higher than 1 or lower than 0 were discarded. This allow going from 61 to more than 800 spectra. Noised data augmentation is a common technique used in deep learning to reduce overfitting of small dataset. ${ }^{43}$

Secondly, we made a feature (i.e. spectral) augmentation on calibration and validation sets. We apply an all possibilities approach combining and keeping the different pretreated spectra, including the original one. For each sample, feature augmentation was applied by generating 12 new spectra using pretreatments based on Haar transform, Gaussian derivatives, SVG, SNV, and different degrees of MSC.

A convolutional neural network composed of three convolutional layers followed by two dense layers was fitted to the calibration data. Binary cross entropy was used as the loss function. In order to avoid overfitting, a dropout of $20 \%$ of features was applied between layers. The model was calibrated using fivefold cross validation.

Model performance was estimated based on a confusion matrix and traditional sensitivity, specificity, precision, recall, F1 score, Kappa statistic and overall accuracy. Accuracy is a popular metric that refers to the ability of the model to correctly predict the class label of new or unseen data. In addition to this, sensitivity and specificity are also used to assess how well classifiers can recognize true examples as well as false examples. The Kappa statistic evaluates the pairwise agreement between two different observers, corrected for an expected chance agreement. A Kappa value of 0 indicates chance agreement and 1 shows prefect agreement between the classifier and the ground truth (true classes). Precision can be seen as a measurement of exactness or quality, whereas recall is a measurement of completeness or quantity. The F1 score is the harmonic mean of precision and recall, where an F1 score reaches its best value at 1 (perfect precision and recall) and worst at 0 .

\section{Results}

\section{Chemical evaluation}

Significant variation was observed for all the constituents (Table 2). Sugar displayed the largest variation amongst varieties, with a coefficient of variation $(\mathrm{CV})$ of $75 \%$, followed by proteins (CV $17.9 \%$ ), dry matter (CV 13.7\%) and starch (CV 5.5\%). The analysis of variance showed that the differences between genotypes were highly significant for all parameters.

Dry matter content ranged from $20.24 \%$ to $32.54 \%$ (Table 2). The value of control variety Bete Bete $(32.54 \%)$ was significantly higher than that of control variety Florido $(26.78 \%)$. In the studied panel, $55 \%$ of accessions presented dry matter contents similar to Bete Bete, while eight accessions $(30 \%)$ presented significantly lower dry matter contents (values between 20 and $24 \%$ ). Starch content ranged from $66.86 \%$ to $82.80 \%$, with five varieties presenting a significantly lower content (i.e. Kinabayo, Oriental, Pyramide, St Vincent violet and St Vincent blanc).

Sugars ranged from $0.52 \%$ to $11.6 \%$. The cultivars Oriental, Kinabayo, St Vincent blanc, St Vincent violet and Pyramide had the largest total sugar contents. Proteins ranged from $4.07 \%$ to $7.43 \%$ with cultivars Pyramide, Kinabayo and Sinoua presenting the highest content.

\section{Textural evaluation}

The hardness of the pounded samples ranged from $1.48 \mathrm{~N}$ for Sinoua to $11.75 \mathrm{~N}$ for Bete Bete. 
Table 2. Chemical and textural characteristics of 27 D. alata accessions.

\begin{tabular}{|c|c|c|c|c|c|c|c|c|}
\hline Varieties & Dry matter (\%) & Starch & Proteins & Sugars & Hardness & Cohesiveness & Springiness & Moldability \\
\hline $14 M$ & $29.18 a b c$ & $80.61 \mathrm{abcd}$ & 5.66 cde & 2.05 efhhi & 7.20 bcdef & 0.20 def & $0.20 \mathrm{fghi}$ & $2.00 \mathrm{~b}$ \\
\hline Sinoua & 21.07 ef & $76.13 \mathrm{f}$ & $7.42 \mathrm{a}$ & $2.43 \mathrm{efgh}$ & $1.48 \mathrm{k}$ & $0.50 a b$ & $0.75 a b$ & $1.00 \mathrm{a}$ \\
\hline $74 \mathrm{~F}$ & $30.14 a b c$ & 78.82 bcdef & 5.47 cdef & $1.24 \mathrm{hij}$ & $5.10 \mathrm{ck}$ & $0.15 \mathrm{f}$ & $0.12 \mathrm{hi}$ & $1.00 \mathrm{a}$ \\
\hline Ptris & $30.03 a b c$ & 79.19 bcdef & 4.95 cdefgh & 2.38 efgh & 3.57 hijk & $0.11 \mathrm{f}$ & $0.09 \mathrm{i}$ & $1.00 \mathrm{a}$ \\
\hline Tagabe & $31.43 \mathrm{a}$ & 80.86 abcd & $4.36 \mathrm{fgh}$ & 2.37 efgh & 8.13 bcde & 0.20 ef & 0.31 defghi & $1.33 \mathrm{ab}$ \\
\hline Malalagi & $29.37 a b c$ & $81.56 a b c$ & $4.11 \mathrm{gh}$ & 2.75 defg & $5.04 \mathrm{ek}$ & $0.16 \mathrm{a}$ & 0.18 fghi & $1.00 \mathrm{a}$ \\
\hline Toufi-Tetea & $30.16 a b c$ & $81.29 a b c$ & 4.91 cdefgh & 1.41 ghij & 7.49 bcdef & 0.24 def & 0.33 defghi & $2.00 \mathrm{~b}$ \\
\hline Peter & $26.91 \mathrm{~cd}$ & 79.21 bcdef & $4.61 \mathrm{efgh}$ & $3.87 \mathrm{~cd}$ & $7.03 \mathrm{bh}$ & $0.21 \mathrm{def}$ & 0.26 efghi & $2.00 \mathrm{~b}$ \\
\hline Noulelcae & $31.55 \mathrm{a}$ & $82.80 \mathrm{a}$ & $4.23 \mathrm{fgh}$ & 1.75 fghij & 7.98 bcdef & $0.22 \mathrm{def}$ & 0.26 defghi & $1.67 \mathrm{ab}$ \\
\hline Nureangdan & $27.13 \mathrm{bcd}$ & 78.87 bcdef & 5.22 cdefgh & $2.46 \mathrm{efgh}$ & $5.02 \mathrm{ek}$ & $0.37 \mathrm{bcd}$ & $0.51 \mathrm{~cd}$ & $2.00 \mathrm{~b}$ \\
\hline Divin & $29.29 a b c$ & 77.20 ef & $5.67 \mathrm{cde}$ & 2.18 efgh & $6.04 \mathrm{bh}$ & 0.15 def & 0.15 ghi & $1.00 \mathrm{a}$ \\
\hline Florido & $26.78 \mathrm{~cd}$ & 78.33 cdef & $4.40 \mathrm{fgh}$ & $3.76 \mathrm{~d}$ & 5.50 ej & $0.21 \mathrm{def}$ & 0.32 defghi & $1.00 \mathrm{a}$ \\
\hline Tiviolet & 23.10 ef & 77.80 def & 5.35 cdefg & $4.01 \mathrm{~cd}$ & $4.41 \mathrm{fk}$ & $0.43 a b c$ & 0.64 bc & $1.00 \mathrm{a}$ \\
\hline H4X 131 & 22.74 ef & 80.50 abcde & $5.85 \mathrm{fgh}$ & $0.52 \mathrm{j}$ & $2.83 \mathrm{ijk}$ & 0.33 cde & 0.50 cde & $1.00 \mathrm{a}$ \\
\hline H4X 172 & $29.36 \mathrm{abc}$ & 80.38 abcde & 4.77 defgh & $3.07 \mathrm{def}$ & 7.84 bcdef & $0.23 \mathrm{def}$ & 0.35 defgh & $1.33 \mathrm{ab}$ \\
\hline H 4 X 200 & $31.31 \mathrm{a}$ & $82.66 \mathrm{a}$ & 4.83 defgh & $1.20 \mathrm{hij}$ & $9.02 a b c$ & $0.25 \mathrm{def}$ & 0.37 defg & $1.67 \mathrm{ab}$ \\
\hline Roujol & $29.80 a b c$ & $81.31 \mathrm{abc}$ & 4.51 efgh & 2.04 efghi & $9.77 \mathrm{ab}$ & $0.23 \mathrm{def}$ & 0.39 defg & $2.00 \mathrm{~b}$ \\
\hline $\mathrm{H} 4 \mathrm{X} 274$ & $31.00 a b$ & $80.76 \mathrm{abcd}$ & 5.01 cdefgh & $2.49 \mathrm{efgh}$ & 8.10 bcde & $0.27 \mathrm{def}$ & $0.39 \mathrm{defg}$ & $1.33 \mathrm{ab}$ \\
\hline Dou & $31.46 \mathrm{a}$ & $82.00 a b$ & $4.30 \mathrm{fgh}$ & $2.22 \mathrm{abcd}$ & 8.68 abcd & 0.33 cde & $0.39 \mathrm{def}$ & $2.00 \mathrm{~b}$ \\
\hline Kabusa & $31.29 \mathrm{a}$ & 78.61 bcdef & 4.95 cdefgh & 3.33 de & $1.73 \mathrm{k}$ & $0.46 a b c$ & $0.71 a b c$ & $1.00 \mathrm{a}$ \\
\hline Kinabayo & 21.38 ef & $66.86 \mathrm{~h}$ & $7.01 \mathrm{ab}$ & $7.36 \mathrm{~b}$ & $2.20 \mathrm{jk}$ & $0.45 a b c$ & $0.63 \mathrm{bc}$ & $1.00 \mathrm{a}$ \\
\hline Oriental & $23.69 \mathrm{def}$ & $70.41 \mathrm{~g}$ & $4.07 \mathrm{~h}$ & $11.69 \mathrm{a}$ & $2.72 \mathrm{ijk}$ & $0.53 \mathrm{a}$ & $0.63 \mathrm{bc}$ & $1.00 \mathrm{a}$ \\
\hline Bete Bete & $32.54 \mathrm{a}$ & 80.54 abcde & 5.28 cdefgh & 2.17 efgh & 11.75 a & 0.22 def & 0.32 defghi & $2.00 \mathrm{~b}$ \\
\hline Plimbite & $28.70 a b c$ & 78.71 bcdef & $6.12 b c$ & $0.81 \mathrm{ij}$ & 3.85 ghijk & $0.24 \mathrm{def}$ & 0.30 defghi & $1.00 \mathrm{a}$ \\
\hline Pyramide & $20.24 \mathrm{f}$ & $70.06 \mathrm{~g}$ & $7.43 \mathrm{a}$ & $5.01 \mathrm{C}$ & $4.41 \mathrm{fk}$ & $0.46 a b c$ & $0.65 \mathrm{bc}$ & $1.00 \mathrm{a}$ \\
\hline St Vincent blanc & 22.80 ef & $70.84 \mathrm{~g}$ & 5.42 cdef & $6.87 \mathrm{~b}$ & $2.75 \mathrm{ijk}$ & 0.57 a & $0.90 \mathrm{a}$ & $1.00 \mathrm{a}$ \\
\hline St Vincent violet & $24.48 \mathrm{de}$ & $71.46 \mathrm{~g}$ & $6.14 \mathrm{bc}$ & $6.28 \mathrm{~b}$ & $3.70 \mathrm{gk}$ & $0.46 a b c$ & $0.74 a b$ & $1.00 \mathrm{a}$ \\
\hline Maximum & 32.54 & $82.80^{\circ}$ & 7.43 & 11.69 & 11.75 & 0.57 & 0.90 & 2.00 \\
\hline Minimum & 20.24 & 66.86 & 4.07 & 0.52 & 1.48 & 0.11 & 0.09 & 1.00 \\
\hline Mean & 27.66 & 78.07 & 5.26 & 3.25 & 5.68 & 0.30 & 0.42 & 1.35 \\
\hline Standard deviation & 3.79 & 4.32 & 0.94 & 2.42 & 2.70 & 0.13 & 0.22 & 0.44 \\
\hline $\begin{array}{l}\text { Coefficient of } \\
\text { variation (\%) }\end{array}$ & 13.70 & 5.53 & 17.79 & 74.44 & 47.60 & 44.12 & 51.41 & 32.59 \\
\hline$p$-Value & $<0.001$ & $<0.001$ & $<0.001$ & $<0.001$ & $<0.001$ & $<0.001$ & $<0.001$ & $<0.001$ \\
\hline
\end{tabular}

Different letters indicate statistically significant differences between genotypes.

Values in bold represent a binary classification of texture attributes. If a value is strictly higher than the attribute average, the genotype is considered as having the respective texture attribute (e.g. hard for hardness or cohesive for cohesiveness).

Amongst the accessions, 44\% presented hardness values similar to Bete Bete (not significantly different), while others presented significantly $(\mathrm{p}<0.05)$ lower values, including the control variety Florido. Cohesiveness ranged from 0.11 to 0.57 . Bete Bete and Florido presented very similar cohesiveness values $(0.22$ and 0.21$)$. Eight accessions presented significantly $(\mathrm{p}<0.05)$ higher cohesiveness values than the control varieties. Springiness ranged from 0.09 to 0.90. Bete Bete and Florido presented identical springiness values (0.32). Eight accessions presented significantly higher $(\mathrm{p}<0.05)$ springiness values than the control varieties.

Moldability ranged from 2 to 1 with seven genotypes regarded as moldable (i.e. $14 \mathrm{M}$, Toufi Tetea, Peter, Noulelcae, H4X200, Roujol, Dou and Bete Bete). One of the two control varieties (i.e. Florido) was characterized as not moldable.

\section{Relationships between main variables}

The correlation analysis (Table 3) revealed very highly significant linear correlations between the main chemical parameters analyzed. Dry matter was positively correlated with starch and negatively correlated with protein and sugar contents. There was also a very highly significant linear correlation between the five texture parameters analyzed. Springiness was positively correlated with cohesiveness $\left(\mathrm{R}^{2}=0.97\right)$. Hardness was negatively correlated with springiness and cohesiveness.

The correlation coefficients between chemical and textural parameters revealed some significant relationships. Dry matter and starch were both positively correlated with hardness and negatively correlated with springiness and cohesiveness. Sugars and proteins were both positively correlated with cohesiveness and springiness. 
Table 3. Table of correlations ( $r$ ) for the main continuous variables.

\begin{tabular}{|c|c|c|c|c|c|c|}
\hline Variables & 1 & 2 & 3 & 4 & 5 & 6 \\
\hline 1. Dry matter & - & & & & & \\
\hline 2. Starch & $0.762^{\star \star \star a}$ & - & & & & \\
\hline 3. Proteins & $-0.592^{\star \star \star}$ & 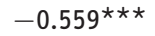 & - & & & \\
\hline 4. Sugars & $-0.541^{\star \star \star}$ & $-0.807^{\star \star \star}$ & $0.061^{\mathrm{ns}}$ & - & & \\
\hline 5. Hardness & $0.638^{\star * \star}$ & $0.584^{\star \star \star}$ & $-0.416^{\star \star}$ & $-0.401^{\star *}$ & - & \\
\hline 6. Cohesiveness & $-0.673^{\star \star \star}$ & $-0.641^{\star \star \star}$ & $0.344^{\star *}$ & $0.601^{\star \star \star}$ & $-0.503^{\star \star \star}$ & - \\
\hline 7. Springiness & $-0.656^{\star \star \star}$ & $-0.598^{\star \star \star}$ & $0.354^{\star \star}$ & $0.527^{\star \star \star}$ & $-0.476^{\star \star \star}$ & $0.958^{\star \star \star}$ \\
\hline
\end{tabular}

aLevel of significance: ns (not significant).

${ }^{\star} p<0.05 ;{ }^{* \star} p<0.01 ;{ }^{\star \star \star} p<0.0001$.
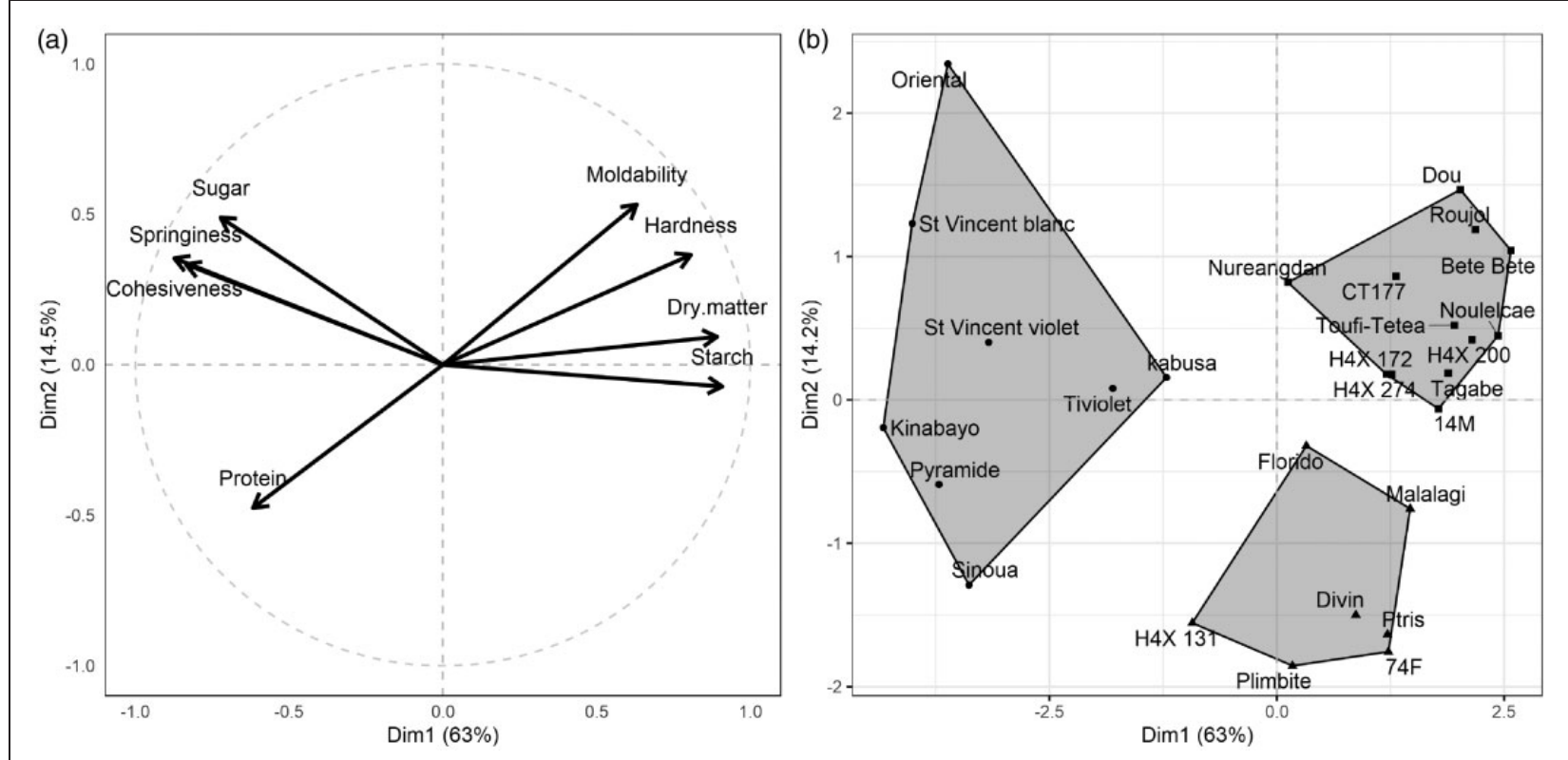

Figure 1. Principal component analysis of the main variables (a) and hierarchical clustering on principal components for the 27 individuals (b).

The principal component analysis conducted on the data matrix indicated the respective contribution of the seven variables to the projection, with dimensions 1 and 2 explaining respectively 62.97 and $14.54 \%$ of total variance (Figure 1). Dimension 1 was negatively linked with the attributes cohesiveness $(\mathrm{r}=-0.87), \quad$ springiness $\quad(\mathrm{r}=-0.83), \quad$ sugars $(\mathrm{r}=-0.72)$ and proteins $(\mathrm{r}=-0.62)$, while it was positively linked with starch $(\mathrm{r}=0.91)$, dry matter $(\mathrm{r}=0.90)$, hardness $(\mathrm{r}=0.80)$ and moldability $(r=0.63)$. The positive side of the second dimension was primarily linked with moldability $(r=0.56)$. The protein content was also linked with the negative side of the third dimension $(\mathrm{r}=0.56)$.

The hierarchical clustering on principal components revealed three main groups of varieties at the extremities of each dimension. The group including the control genotype Bete Bete was characterized by high dry matter, starch content and hardness, and good moldability. The group including the second control (i.e. Florido) differed from the first by a higher protein content and lower hardness and moldability. Finally, the last group contained genotypes with high sugar and protein contents, high cohesiveness and springiness, and low moldability.

Figure 2 shows the results of the principal component coordinates for moldable and non-moldable individuals. The upper left window of the plot groups a mix of non-moldable samples and all the moldable samples but one. On the other hand, the other windows were mainly populated with nonmoldable individuals.

\section{Calibration and validation of predictive models}

The results in Table 4 show the calibration performance for chemical and textural attributes. The chemical attribute models performed well during the calibration step $\left(\mathrm{R}_{\mathrm{C}}^{2}>0.84\right.$ and $\left.\mathrm{R}_{\mathrm{CV}}^{2}>0.79\right)$. On the other hand, all the texture parameters showed $\mathrm{R}^{2} \mathrm{C}$ values below 0.8 , except hardness $(0.83)$. The good performance of the chemical models was 


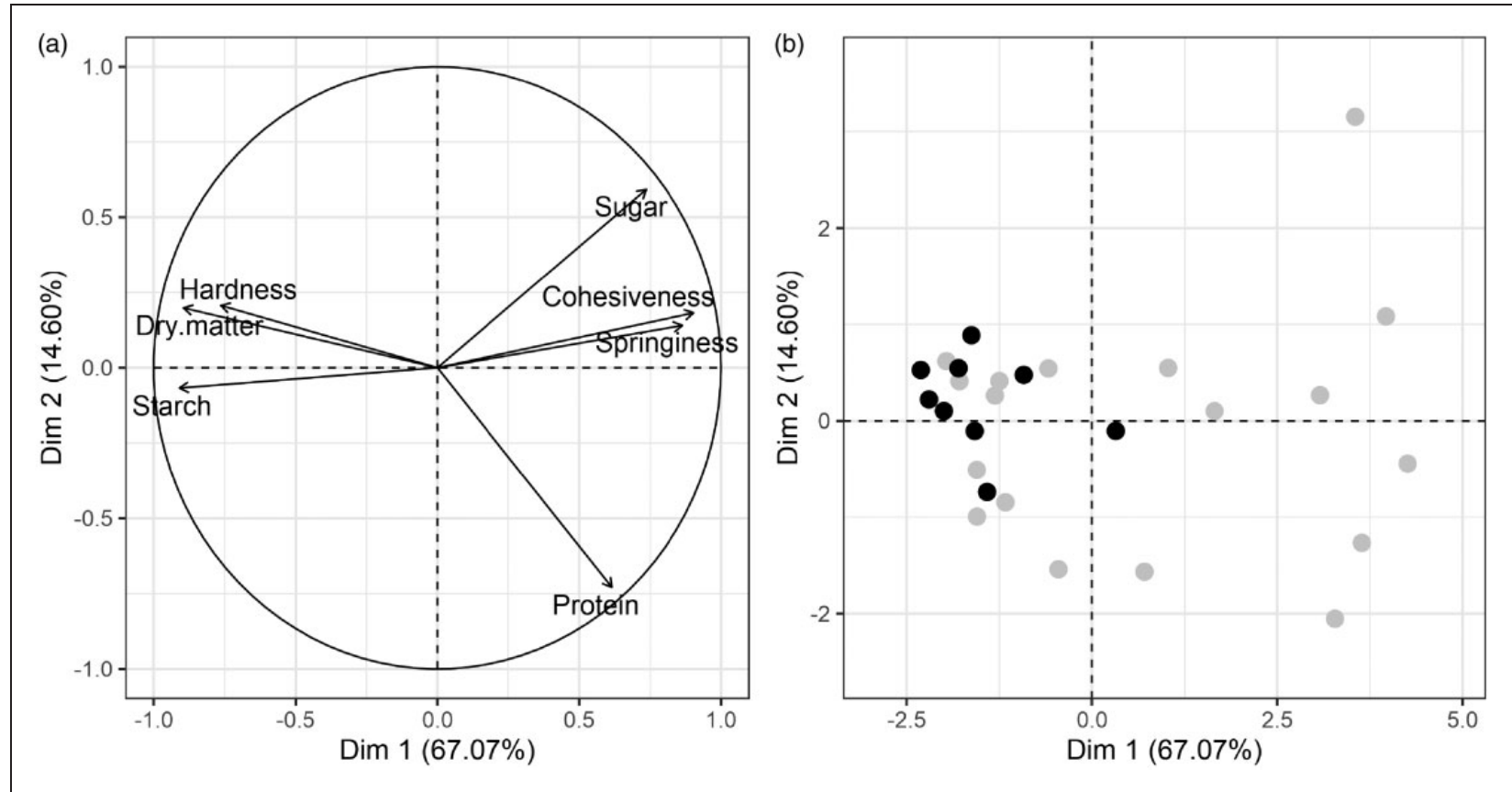

Figure 2. Principal component analysis of the main variables (a) and principal component coordinates for moldable (black) and nonmoldable (gray) individuals (b).

Table 4. Model performance metrics for the calibration (C), cross-validation (CV), and prediction (P) steps.

\begin{tabular}{|c|c|c|c|c|c|c|c|c|c|c|c|c|}
\hline \multirow[b]{2}{*}{ Constituent } & \multicolumn{2}{|c|}{ Procedure } & \multirow[b]{2}{*}{ SEL } & \multicolumn{3}{|c|}{ Calibration } & \multicolumn{2}{|c|}{ Cross-validation } & \multicolumn{4}{|c|}{ Validation } \\
\hline & Model & $\begin{array}{l}\text { Latent } \\
\text { variables }\end{array}$ & & $\mathrm{N}_{\mathrm{C}}$ & $\mathrm{SE}_{\mathrm{C}}$ & $\mathrm{R}_{\mathrm{C}}^{2}$ & $\mathrm{SE}_{\mathrm{CV}}$ & $\mathrm{R}_{\mathrm{CV}}^{2}$ & $N_{p}$ & $\mathrm{SE}_{\mathrm{p}}$ & $\mathrm{R}_{\mathrm{P}}^{2}$ & $\mathrm{SD} / \mathrm{SE} \mathrm{E}_{\mathrm{P}}$ \\
\hline Dry matter (\%) & MPLS & 15 & 1 & 141 & 1.44 & 0.84 & 1.64 & 0.79 & 37 & 1.58 & 0.85 & 2.13 \\
\hline Protein (\%) & MPLS & 15 & 2 & 136 & 0.18 & 0.96 & 0.24 & 0.92 & 37 & 0.29 & 0.88 & 2.77 \\
\hline Sugar (\%) & MPLS & 9 & 3 & 136 & 0.32 & 0.96 & 0.42 & 0.93 & 38 & 0.56 & 0.93 & 3.49 \\
\hline Starch (\%) & MPLS & 15 & 3 & 146 & 0.91 & 0.91 & 1.21 & 0.83 & 37 & 1.46 & 0.89 & 2.67 \\
\hline Hardness $(N)$ & NIPALS & 20 & 1 & 54 & 1.66 & 0.83 & 2.17 & 0.73 & 19 & 1.68 & 0.58 & 1.68 \\
\hline Cohesiveness (dimensionless) & MPLS & 9 & 1 & 52 & 0.08 & 0.55 & 0.10 & 0.23 & 21 & 0.11 & 0.55 & 1.35 \\
\hline Springiness (dimensionless) & MPLS & 9 & 1 & 54 & 0.13 & 0.57 & 0.16 & 0.41 & 21 & 0.19 & 0.52 & 1.24 \\
\hline
\end{tabular}

SEL: standard error of laboratory reference measurement; N: number of samples; SE: standard error; $\mathrm{R}^{2}$ : coefficient of determination; SD: standard deviation; MPLS: modified partial least square regression model; NIPALS: nonlinear estimation by Iterative partial least squares regression.

confirmed when the model was validated against the validation data set (Figure $3, \mathrm{R}_{\mathrm{P}}^{2}>0.85$ ). The performance to deviation ratio $\left(\mathrm{SD} / \mathrm{SE}_{\mathrm{P}}\right)$ showed that the model for dry matter, protein, sugar and starch content, with values higher than two, could be considered good for screening purposes. ${ }^{44,45}$ However, the calibration performance for hardness $\left(\mathrm{R}_{\mathrm{P}}^{2}=0.58, \mathrm{SD} / \mathrm{SE}_{\mathrm{P}}=\right.$ $1,68)$, cohesiveness $\left(\mathrm{R}_{\mathrm{P}}^{2}=0.55, \mathrm{SD} / \mathrm{SE}_{\mathrm{P}}=1.35\right)$ and springiness $\left(\mathrm{R}_{\mathrm{P}}^{2}=0.52, \mathrm{SD} / \mathrm{SE}_{\mathrm{P}}=1.24\right)$ displayed a poor predictive performance (Figure 3 ).

Figure 4 presents the confusion matrix and the model performance metrics for the different classification models during the cross-validation (A) and validation (B) steps. The convolutional neural networks exhibited high accuracy $(>0.8)$, except for hardness (0.55), where the model lacked specificity $(0.25)$. For moldability, the model was characterized by very good sensitivity (1), but rather poor specificity (0.636). Springiness and cohesiveness where classified with very good performance metrics.

\section{Discussion}

All the chemical and texture attributes studied were highly variable and their differences between genotypes were highly significant. Among these traits, dry matter and starch, two strongly and positively correlated parameters, are known to affect yam quality. ${ }^{15,21}$ This study showed that dry matter and starch were both negatively correlated with sugar and protein contents. These results tallied with those obtained on root and tuber plants: sweet potato, cassava, taro, potato and yam (i.e. D. alata, D. bulbifera, D. cayenensis-rotundata, D. esculenta, D. nummularia, 


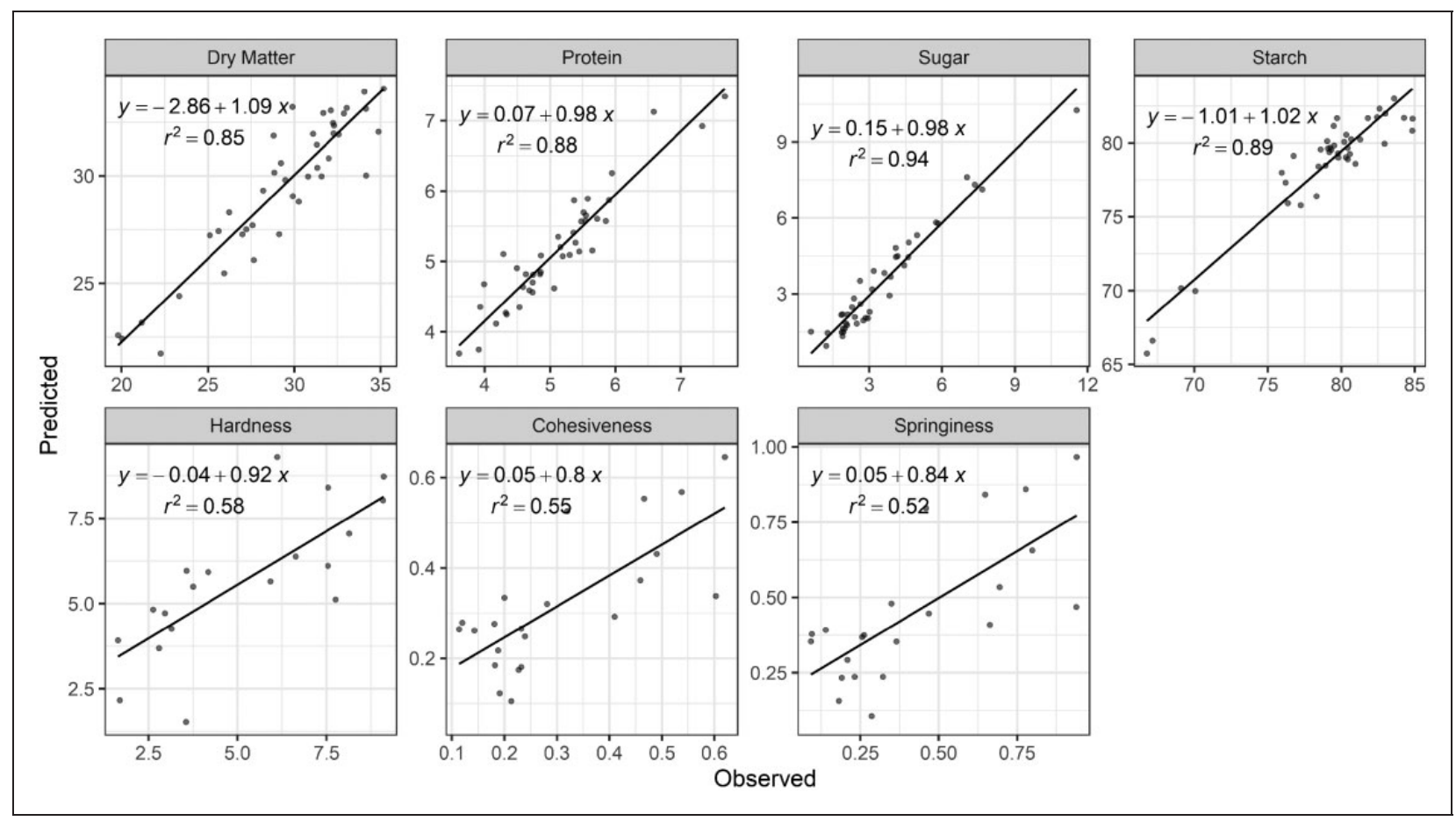

Figure 3. Comparison of observed and predicted values for chemical $(n=41)$ and textural $(n=22)$ attributes during the validation step.

D. pentaphylla and D. transversa). ${ }^{15,46}$ However, on a panel of 48 varieties within the species D. alata, Lebot et al, (2005) showed that dry matter was positively correlated with sugar. ${ }^{15}$ This discrepancy may be due to the longer storage period applied in this study, leading to the breaking of dormancy and starch remobilization to produce sugars. In this particular situation, the sugar content could be negatively correlated to the starch content. Bete Bete, a control variety known for its gustatory qualities, as well as $55 \%$ of the varieties evaluated, had significantly higher dry matter content than the others. Although all but one of the moldable genotypes belonged to the high dry matter varieties, only half of these high dry matter varieties were evaluated as moldable. This result indicated that if dry matter content impacts sensory quality it may be a necessary, but not sufficient, attribute interacting with other traits. Conversely, varieties with the highest sugar (i.e. Oriental, Kinabayo, St Vincent blanc, St Vincent violet and Dou) and protein (i.e. Pyramide, Sinoua, Kinabayo, St Vincent violet and Plimbite) contents were all evaluated as non-moldable.

The texture parameters also displayed a high degree of variability. Hardness is one of the most important texture parameters in product evaluation. ${ }^{34,35}$ Brunnschweiler et al., (2005) showed that varieties of high quality $D$. rotundata were much firmer than those of D. alata. ${ }^{47}$ In this study, all the moldable genotypes belonged to varieties classified as hard. But this class also contained some nonmoldable genotypes. This suggests that there could be a hardness threshold below which yam can no longer be moldable. Conversely, high hardness does not automatically imply that the product will be of high quality. Hardness threshold identification could be an important criterion for selecting $D$. alata varieties.

Cohesiveness is the degree of malleability of a product. It is the way in which a product or paste is easily molded with the fingers into a ball or spherical shape. ${ }^{47}$ In this study, eleven varieties presented high cohesiveness values. Amongst them, only one (Dou) was moldable. The varieties with low cohesiveness values belonged to both the moldable and nonmoldable categories. Again, the result suggested a cohesiveness threshold above which yams are no longer moldable. On the other hand, low cohesiveness does not automatically imply that the product will be moldable.

Otegbayo et al. (2007) showed that difficult-to-mold D. alata varieties have high elasticity values. ${ }^{27}$ This is in accordance with the high correlation found between springiness and cohesiveness. All the springy genotypes where not moldable, while the rigid ones included both types (i.e. moldable and non-moldable).

The models for the quantitative prediction of physico-chemical parameters (i.e. dry matter, proteins, starch and sugars) showed a good performance, unlike the texture parameters (i.e. hardness, cohesiveness, springiness). These results are consistent with previous studies which found a good calibration performance for dry matter, starch, protein and sugars on different yam, taro and cassava species. ${ }^{12,46,48,49}$ The relatively small number of samples available for texture traits calibration may result in reduced 


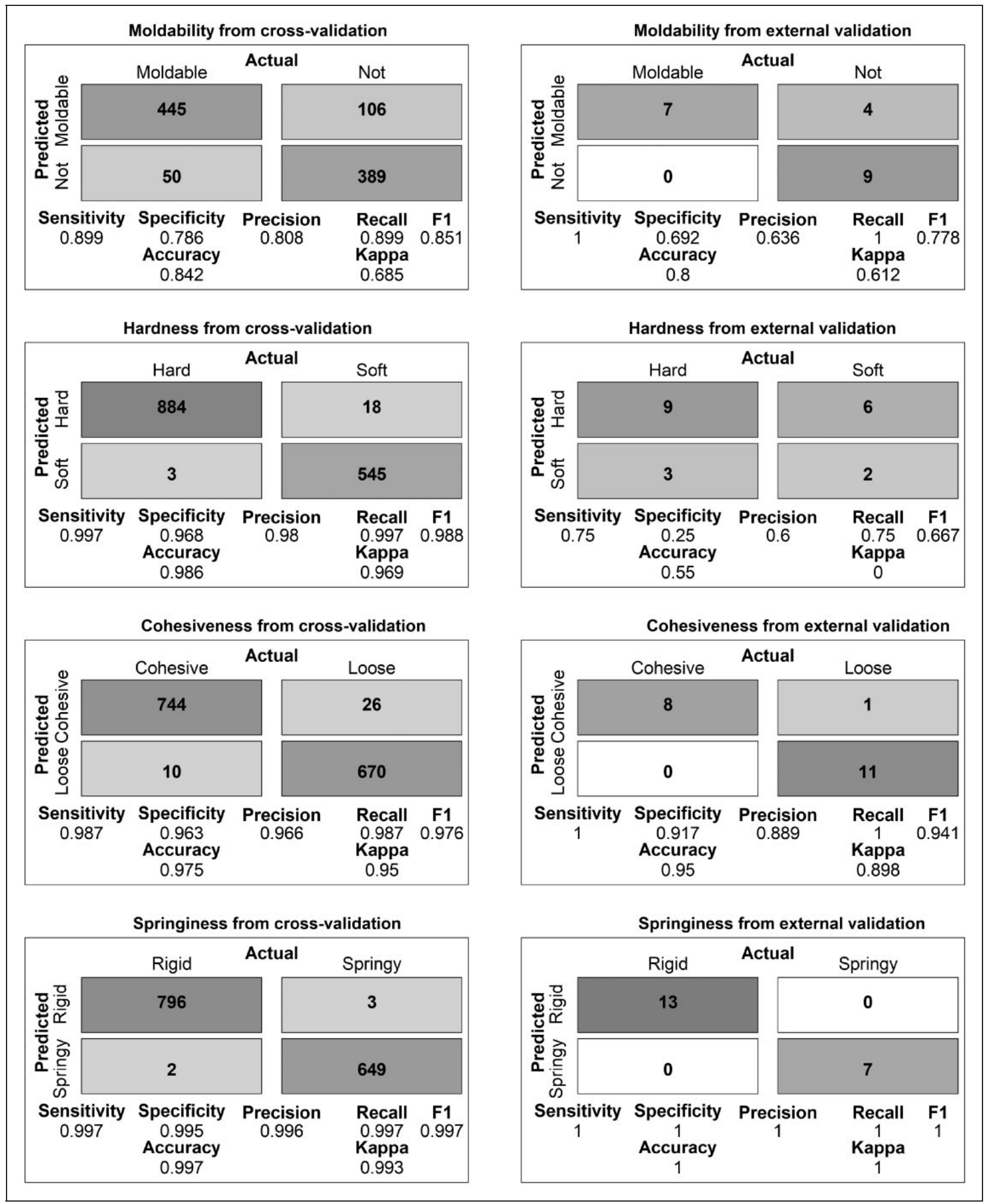

Figure 4. Confusion matrix, sensitivity, specificity, precision, recall, F1-measure, accuracy and Kappa data for yam texture classification models during cross-validation (left plots) and validation (right plots) steps.

performance and robustness. Current prediction models should benefit from supplementary calibration data and external validation.

However, while regression models failed to predict texture parameters, classification models provided an accurate tool for qualitative screening varieties for their moldability, springiness and cohesiveness. Only the hardness classification model still exhibit poor performance and seem to be prone to overfitting. Indeed, accuracy decrease between calibration and validation steps (i.e. 0.99 to 0.55 ) suggest such an overfitting. 


\section{Conclusion}

Despite high variability in the main chemical and texture variables studied, it was not possible to define a common profile discriminating between moldable and non-moldable individuals. However, although the results failed to identify a precise profile for moldable genotypes, they enabled us to ascertain what leads to a lack of moldability: high protein content, low hardness, or high cohesiveness. These minimum requirements could be very useful prerequisites for breeders to screen and discard low quality genotypes.

Moreover, the results confirmed that near infrared spectrometry could be used for rapid screening of dry matter, protein, sugar and starch contents in D. alata yam varieties. Although texture parameters could not be satisfactorily quantitatively predicted, the classification algorithm proved to be accurate for qualitative prediction. For breeding purposes, using thresholds or classification algorithms to screen for texture quality traits seems to be a good compromise between precision and speed. Using near infrared spectra with binary classification modeling allows for highthroughput phenotyping of moldability, cohesiveness and springiness.

\section{Acknowledgements}

We acknowledge the CRB-PT biological resource center (INRA/CIRAD, France) for providing plant material samples. We would also like to thank Jocelyne Leinster, Pascale Bade and Valerius Calif for their technical assistance for NIR spectroscopy acquisition. English Language editing and review services supplied by Peter Biggins.

\section{Declaration of conflicting interests}

The author(s) declared no potential conflicts of interest with respect to the research, authorship, and/or publication of this article.

\section{Funding}

The author(s) disclosed receipt of the following financial support for the research, authorship, and/or publication of this article: This study was made possible by the RTBfood project funded by the Bill and Melinda Gates Foundation [OPP1178942], for which we should like to thank the various leaders. The authors acknowledge funding provided by the ERDF Cavalbio project, financed by Région Guadeloupe and the European Union, which contributed to field preparation and maintenance.

\section{ORCID iDs}

Denis Cornet (D) https://orcid.org/0000-0001-9297-2680 Amani Michel Kouakou (D) https://orcid.org/0000-00017232-0554

\section{References}

1. Coursey DG. Yams. London: Longmans, 1967.

2. Cornet D, Sierra J and Bonhomme R. Characterization of the photosynthetic pathway of some tropical food yams (Dioscorea spp.) using leaf natural 13C abundance. Photosynthetica 2007; 45: 303-305.

3. Abraham K and Nair PG. Floral biology and artificial pollination in Dioscorea alata L. Euphytica 1990; 48: 45-51.

4. Mignouna D, Mank A, Ellis N, et al. A genetic linkage map of water yam (Dioscorea alata L.) based on AFLP markers and QTL analysis for anthracnose resistance. Theor Appl Genet 2002; 105: 726-735.

5. Cornet D, Sierra J, Tournebize R, et al. Bayesian network modeling of early growth stages explains yam interplant yield variability and allows for agronomic improvements in West Africa. Eur J Agron 2016; 75: 80-88.

6. FAOTSTAT 2018. www.fao.org/faostat/en/\#data/FO (accessed 18 March 2020).

7. Orkwor GC, Asiedu R and Ekanayake IJ. Food yams: advances in research. Umudike, Nigeria: IITA and NRCRI, 1997.

8. Egesi NC, Asiedu R, Egunjobi JK, et al. Genetic diversity of organoleptic properties in water yam (Dioscorea alata L.). J Sci Food Agric 2003; 83: 858-865.

9. Doumbia S, Toure $M$ and Mahyao A. Commercialisation de l'igname en côte d'Ivoire, état actuel et perspectives d'évolution. Cahiers Agricultures 2006; 15: 273-277.

10. Egesi CN and Asiedu R. Analysis of yam yields using the additive main effects and mutiplicative interaction (AMMI) model. Afr Crop Sci J 2002; 10: 195-201.

11. Ano G, Anaïs $G$ and Chidiac A. Creation et utilisation de varietes resistantes aux maladies, elements essentiels de la diversification agricole en Guadeloupe. Phytoma 2002; 551: 36-37.

12. Lebot V, Champagne A, Malapa R, et al. NIR determination of major constituents in tropical root and tuber crop flours. J Agric Food Chem 2009; 57: 10539-10547.

13. Arnau G, Nemorin A, Maledon E, et al. Advances on polyploid breeding in yam D. alata. In: Proceedings of the first international symposium on roots, rhizomes, tubers, plantains, bananas and papaya, Santa Clara, Cuba, 7-10 November 2011.

14. Martin FW. Tropical yams and their potential. Part. 2: Dioscorea bulbifera. USDA Agric Handb 1974; 466: $1-19$.

15. Lebot V, Malapa R, Molisale T, et al. Physico-chemical characterisation of yam (Dioscorea alata $\mathrm{L}$ ) tubers from Vauatu. Genet Resour Crop Evol 2006; 53: 1199-1208.

16. Akissoe HN, Mestres C, Hounhouigan DJ, et al. Sensory and psychochemical quality quality of pounded yam: Varietal and storage effects. J Food Process Preserv 2009; 33: 75-90.

17. Dufie BF. Characterizaion of water yam (Dioscorea alata) for existing and potential food products. $\mathrm{PhD}$ Thesis, Kwame Nkrumah University of Science and Technology, Ghana, 2009.

18. Brunnschweiler J, Mang D, Farah Z, et al. Structuretexture relationships of fresh pastes prepared from different yam (Dioscorea spp) varieties. $L W T-$ Food $S c i$ Technol 2006; 39: 762-769.

19. Otegbayo B, Aina J, Asiedu R, et al. Microstructure of boiled yam (Dioscorea spp) and its implication for assessment of textural quality. J Texture Stud 2005; 36: $324-332$. 
20. Nindjin C, Otokoré D, Hauser S, et al. Determination of relevant sensory properties of pounded yams (Dioscorea spp.) using a locally based descriptive analysis methodology. Food Qual Prefer 2007; 18: 450-459.

21. Otegbayo B, Asiedu R and Bokanga $M$. Physicochemical properties of yam starch: effect on textural quality of yam food product (pounded yam). $J$ Food Agric Environ 2011; 9: 145-150.

22. Friedman HH, Whitney JE and Szczesniak AS. The texturometer - a new instrument for objective texture measurement. J Food Sci 1963; 28: 390-396.

23. Yasumatsu K, Sawada K, Moritaka S, et al. Whipping and emulsifying properties of soybean products. $\mathrm{Agr}$ Biol Chem 1972; 36: 719-727.

24. Gibert O, Giraldo A, Uclés-Santos JR, et al. A kinetic approach to textural changes of different banana genotypes (Musa sp.) cooked in boiling water in relation to starch gelatinization. J. Food Eng 2010; 98: 471-479.

25. Sajeev MS, Sreekumar J, Unnikrishnan M, et al. Kinetics of thermal softening of cassava tubers and rheological modeling of the starch. J Food Sci Technol 2010; 47: 507-518.

26. Polycarp D. Textural characteristics of seven different yams (Dioscorea species) grown and consumed in Ghana. Int J Sci Technol Res 2010; 6: 281-284.

27. Otegbayo B, Aina J, Abbey L, et al. Texture profile analysis applied to pounded yam. J Texture Stud 2007; 38: 355-372.

28. Huang Y, Xu F, Hu H, et al. Development of a predictive model to determine potato flour content in potato-wheat blended powders using near-infrared spectroscopy. Int J Food Prop 2018; 21: 2030-2036.

29. Huang HB, Yu HY, Xu HR, et al. Near infrared spectroscopy for on/in-line monitoring of quality in foods and beverages: a review. J. Food Eng 2008; 87: 303-313.

30. Zum Felde T, Burgos G, Espinoza J, et al. Screening for b-carotène, iron, zinc, starch, individual sugars and protein in sweetpotato germplasm by Near-Infrared Reflectance. In: 15th triennial symposium of the international society for tropical root crops, Lima, Peru, 2009.

31. Arnau G, Bhattacharjee R, Mn S, et al. Understanding the genetic diversity and population structure of yam (Dioscorea alata L.) using microsatellite markers. PLoS One 2017; 12: e0174150. doi.org/10.1371/journal. pone.0174150.

32. Brunnschweiler J. Structure and texture of yam (Dioscorea spp.) and processed yam products. $\mathrm{PhD}$ Thesis, Swiss Federal Institute of Technology, Switzerland, 2004.

33. Bricas N, Vernier P, Ategbo E, et al. The development of pounded yam machine in West Africa. J Res Dev 1997; 44: 100-114.

34. Bourne MC. Food texture and viscosity: concept and measurement. San Diego, CA: Academic Press, 2002.
35. Rosenthal AJ. Food texture: Measurement and perception. Aspen: Springer; 1999.

36. Shenk JS and Westerhaus MO. Analysis of agriculture and food products by near-infrared reflectance spectroscopy. Port Matilda, PA: Infrasoft, 1993.

37. Rossard V, Boulet JC, Gogé F, et al. ChemFlow, chemometrics using galaxy. F1000Research 2016; 5: 1671.

38. Wu JG, Shi $\mathrm{CH}$ and Zhang XM. Estimating the amino acid composition in the milled rice powder by nearinfrared reflectance spectroscopy. Field Crops Res 2002; 75: 1-7.

39. Cui $\mathrm{C}$ and Fearn T. Modern practical convolutional neural networks for multivariate regression: applications to NIR calibration. Chemometr Intell Lab 2018; 182: 9-20.

40. Sarin JK, t, Moller NCR, Mohammadi A, et al. Machine learning augmented near-infrared spectroscopy: in vivo follow-up of cartilage defects. Osteoarthr Cartil 2020. DOI: 10.1016/j.joca.2020.12.007.

41. Yang SY, Kwon O, Park Y, et al. Application of neural networks for classifying softwood species using near infrared spectroscopy. J Near Infrared Spectrosc 2020; 28: 5-6.

42. Zhang L, Xiangqian D and Hou R. Classification modeling method for near-Infrared spectroscopy of tobacco based on multimodal convolution neural networks. J Anal Methods Chem 2020; 2020: 9652470.

43. Bae HJ, Kim CW, Kim N, et al. A Perlin noise-based augmentation strategy for deep learning with small data samples of HRCT images. Sci Rep 2018; 8 .

44. Lebot V and Malapa R. Application of near infrared reflectance spectroscopy to the evaluation of yam (Dioscorea alata) germplasm and breeding lines. J Sci Food Agric 2013; 93: 1788-1797.

45. Roberts CA, Workman J and Reeves JB. Near-infrared spectroscopy in agriculture. Agronomy Monographs Volume 44. Madison, WI: ASA, CSSA, SSSA, 2004.

46. Williams PC. Implementation of near-infrared technology. In: Williams P and Norris K (eds), Near-infrared technology in the agriculture and food industries. 2nd ed. St. Paul, MN: American Association of Cereal Chemists, 2001, pp. 145-169.

47. Brunnschweiler J, Luethi D, Handschin S, et al. Isolation, physicochemical characterization and application of yam (Dioscorea spp.) starch as thickening and gelling agent. Starch/Stärke 2005; 57: 107-117.

48. Lebot V, Malapa R and Jung M. Use of NIRS for the rapid prediction of total $\mathrm{N}$, minerals, sugars and starch in tropical root and tuber crops. NZ J Crop Hort Sci 2013; 41: 144-153.

49. Ikeogu UN, Davrieux F, Dufour D, et al. Rapid analyses of dry matter content and carotenoids in fresh cassava roots using a portable visible and near infrared spectrometer (Vis/NIRS). PLoS One 2017; 12: $\mathrm{e} 0188918$. 